\title{
REPORT OF WORKSHOP ON WINDOWLESS GAS PHASE BEAM LINE AT THE NATIONAL SYNCHROTRON LIGHT SOURCE JUNE 29, 1979
}

J. R. GROVER, R. B. KLEMMY, AND J. B. A. MITCHELL Editors

BROOKHAVEN NATONAL LABORATORY

A S S OCI A TED UNIVERS I TIES, IN C. Under Contract No. E:-76mC-02-0016 with the UNITED STATES DEPARTMENT OF ENERGI 
BNL 27004

\author{
REPORT OF WORRSHOP ON \\ WINDOWLESS GAS PHASE BEAM LINE \\ AT THE NATIONAL SYNCHROTRON LICHT SOURCE \\ JUNE 29, 1979
}

J. R. Grover, R. B. Klemm, and J. B. A. Mitchell
Editors

INFORMAI REPORT

B R O OKHAVEN NATIONAL LABORATORY

U P T O N, NE Y Y O K 11973

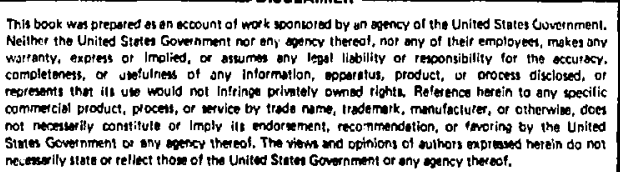




\section{TABLE OF CONTENTS}

page

List of Workshop participants

I. Introduction

II. Administrative Policy 3

III. Monochromator Design 5

IV. Apparatus and Utilities 9

V. Proposed Experiments 13

A. W. A. Chupka, Department of Chemistry, Yale University 14

B. M. 0. Krause, Chemistry Division, Oak RIdge National Lab. 15

C. J. R. Grover and J. B. A. Mitchell, Department of Chemistry, $\begin{array}{ll}\text { Brookhaven National Lab. } & 16\end{array}$

D. C. $-Y . \mathrm{Ng}$, Ames Lab. and Department of Chemistry, 18

Iowa State University, and

J. Berkowitz, Physics Division, Argonne National Lab.

E. J. M. Farrar, Department of Chemistry, University of Rochester

F. R. B. Klemm, Department of Energy and Environment, Brookhaven National Lab., and

D. J. Seery, United Technologies Research Center

vI. Members of Participating Research Team 


\section{LIST OF PARTICIPANIS}

Dr. D. M. Brenner

Prof. W. A. Chupka

Prof. J. M. Farrar

Dr. J. R. Grover

Dr. M. R. Howells

Dr. J. Hudis

Dr. R. B. Klemm

Dr. M. O. Krause

Dr. J.B.A. Mitchell

Dr. M. D. Newton

Dr. M. L. PerIman

Dr. D. J. Seery

Dr. T. Tanzawe

Dr. R. E. Weston
Department of Chemistry

"

II

I"

Accelerator Department

Department of Chemistry

Dept. of Energy \& Environment

Chemistry DIvision

Department of Chemistry

11

11

11

Unfted Technology Research Center

Dept. of Energy \& Environment

Department of Chemistry
BNL

BNL

Yale Univ.

Univ. of Rochester

BNL

BNL

BNL

BNL

ORNL

BNL

BNL

BNL

BNL 


\section{INTRODUCTION}

A workshop was held on the 29th June 1979 to present the design of the Windowless Gas Phase Beamline for the National Synchrotron Light Source and to discuss the proposed research to be performed using this equipment. Participants Included sclentlsts from the Brookhaven National Laboratory, Oak Ridge National Laboratory, Yale UnIversity, the University of Rochester, and United Technologies Research Center. The following report sumnarizes the presentations that were made and also includes contributions from interested sclentists who were unable to attend.

When funding for the National Synchrotron Light Source Project at Brookhaven National Laboratory was announced, it was felt by members of the Chemistry Department that an apparatus should be bullt to exploit synchrotron radiation for the study of atomic and molecular processes in the gas phase. Examination of this concept quickly showed that such an endeavor would represent a fairly large investment and so the decision was made to make this a user's faclilty. The proposed apparatus would be made avallable for use by sclentists from Institutions outside Brookhaven as well as by in-house staff. A prereguisite to the construction of the profect was that there should be surficlent interest from outstde Broothaven, and In order to determine this a workshop was held on Jan. 26, 1978 to discuss proposed usage of the apparatus. Inftial interest displayed at this workshop led to the commencement of a design for a multipurpose sinteraction chamber early in 1978. It was intended that a single large chambel be bullt that would sat1sfy the needs of most prospective users with the ultimate goal of using the synchrotron radiation to examine the reaction products from a crossed beams reactive scattering experiment. 
A description of this apparatus is given in a BNL report that was subsequently produced (Mitchell and Grover, 1978).

The response to this design was mixed, however, and it was decided to concentrate on a single molecular beam approach. A new modular design was produced that will be cheaper to build, and which was felt to be well-suited to this project. Construction was begun in Apr11 1979. This workshop was called to Introduce this design to scientists who had expressed definite interest in using the windowless gas phase beamline and to discuss how their own particular interests might be best served using the equipment ava1lable.

Dr. J. Hudis, Chairman of the Chemistry Department at BNL opened the proceedings with a discussion of the funding of the project. Following this, presentations were made by Dr. M. Howells of the synchrotron design staff on the monochromator design, and by Dr. J. B. A. Mitchell (Chemistry Department, BNL) who outlined the experimental apparatus and support services available to users.

The afternoon session was devoted to presentations of proposed experiments by the prospective users (Section V). These talks focused not only on the signfficance of the Individual Investigations but also on the merits of the NSLS windowless gas phase beam line and the utility of the proposed general experimental chamber (Section IV). In discussions following the presentations, the general concensus was clearly that: (1) all of the prospective users require the photon energles avallable only on a windowless system; and (2) for the most part, the selection of modular utflities to be made avallable ts well suited to the wide range of experimental requirements of this diverse proposed participating research team.

REFERENCES

J. B. A. Mitchell ani J. R. Grover, BNL Report No. 50920, 1978. 


\section{ADMINISTRATIVE POLICY}

\section{(J. Hudis, Chairman, Chemistry Department, BNL)}

The Chemistry Department has great interest in four areas of chemical research at the NSLS. The Chemical Sciences Division in the Department of Energy is encouraging these efforts and is making every attempt to provide us with sufficient funds to support our efforts adequately.

A major reason for the strong backing by DOE is this Department's interest, not only in our own efforts, but in playing a major role in encouraging and supporting the widest possible use of the NSLS by the whole chemical community.

Four groups within this Department have been active for about one and a half years, designing experiments and apparatus and building up groups of outside scientists interested in collaborating with us. We have the prospects of obtaining appreciable amounts of capital equipment money over the next few years and, in addition, have already used FY 78 and 79 money to start bullding the necessary apparatus. However it is apparent that we will not have sufficient funds to support completely the four Participating Research Teams (PRT's) in this Department and the one in DEE which this money is supposed to cover.

The original plans for the NSLS included only two modes of beam line financing and use: 1) facilities constructed by the NSLS and 100\% avallable to users on the basis of a proposal/review procedure and 2) PRT facilities built and financed by experimental groups for which they recelve $75 \%$ of the beam time with the rest available to the general user community.

It is now obvious that there is wuch to be gained, especlally for the first few years of operation, by hybridizing the two approaches described above. Specifically, it is now planned that the NSI,S project and the 
Departments of Chemistry and Energy and Environment will share in the construction of a windowless gas phase beam line with the PRT receiving a fraction of the beam time less than $75 \%$ which will be negotiated with the NSLS project.

The NSLS project is funding the construction of the front end and the monochromator while the Chemistry Department is financing the experimental chambers and assoctated hardware. 
III. MONOCHROMATOR DESIGN

(M. Howells, Accelerator Department, BNL)

The specifications for the windowless gas phase beam line call for as high a photoll flux as possible with moderate wavelength resolution ( $0.25 \AA)$ over a spectral range from 300-2000 ̊. Various monochromator designs have been examined to match these specifications as closely as possible, considerable emphasis being placed on limiting the expense of such a system. The most sultable design appears to be a normal incidence Instrument collecting photons over an angular range of 75 mrad in the horizontal plane and 10 mrad in the vertical. A sketch of this instrument is given in Fig. 1. The photon flux output for this instrument can be estimated using the design parameters for the $700 \mathrm{MeV}$ voV storage ring of the NSLS. These are listed in Table I. It should be possible with clean reflecting surfaces to obtain beams of $\sim 10^{13}$ photons/sec for a bandwidth of v0.25 $\AA$. By changing to gratings with higher groove densities it is possible to Improve on this although the scanning range is subsequently diminished. A list of the properties of this instrument is given in Table II. Technical details Involving the coupling of the monochromator to the synchrotron and of the monochromator Itself are given in references 1 and 2 . Estimates of available photon fluxes from the optical instruments coupled to NSLS, VUV storage ring are given in reference 3. A description of the actual NSLS building and services is found in reference 4 and references 5 and 6 present the detalled descriptions of the enilre NSLS project. A summary of a varlety of the monochromators proposed for use with the NSLS is given in reference 7 . 
6

References

1. J. B. Godel, J. B. Hastings, M. R. Howells, T. Oversluizen, J. C. Schuman, W. C. Thomlinson, and G. P. Willifams. Bir 26136, 1979.

2. M. R. Howells and T. J. Aggus. BNL 26341, 1979.

3. G. P. Williams and M. R. Howe11s. BNL 26121, 1979.

4. J. B. Codel and A. Selfert. BNL 26124, 1979.

5. G. K. Green. BNL 5n595, 1977.

6. A. Ver. Steenbergen. BNL-26250, 1979.

7. M. R. Howells, G. P. Williams, and W. R. McKinney. BNL 26122, 1979. 

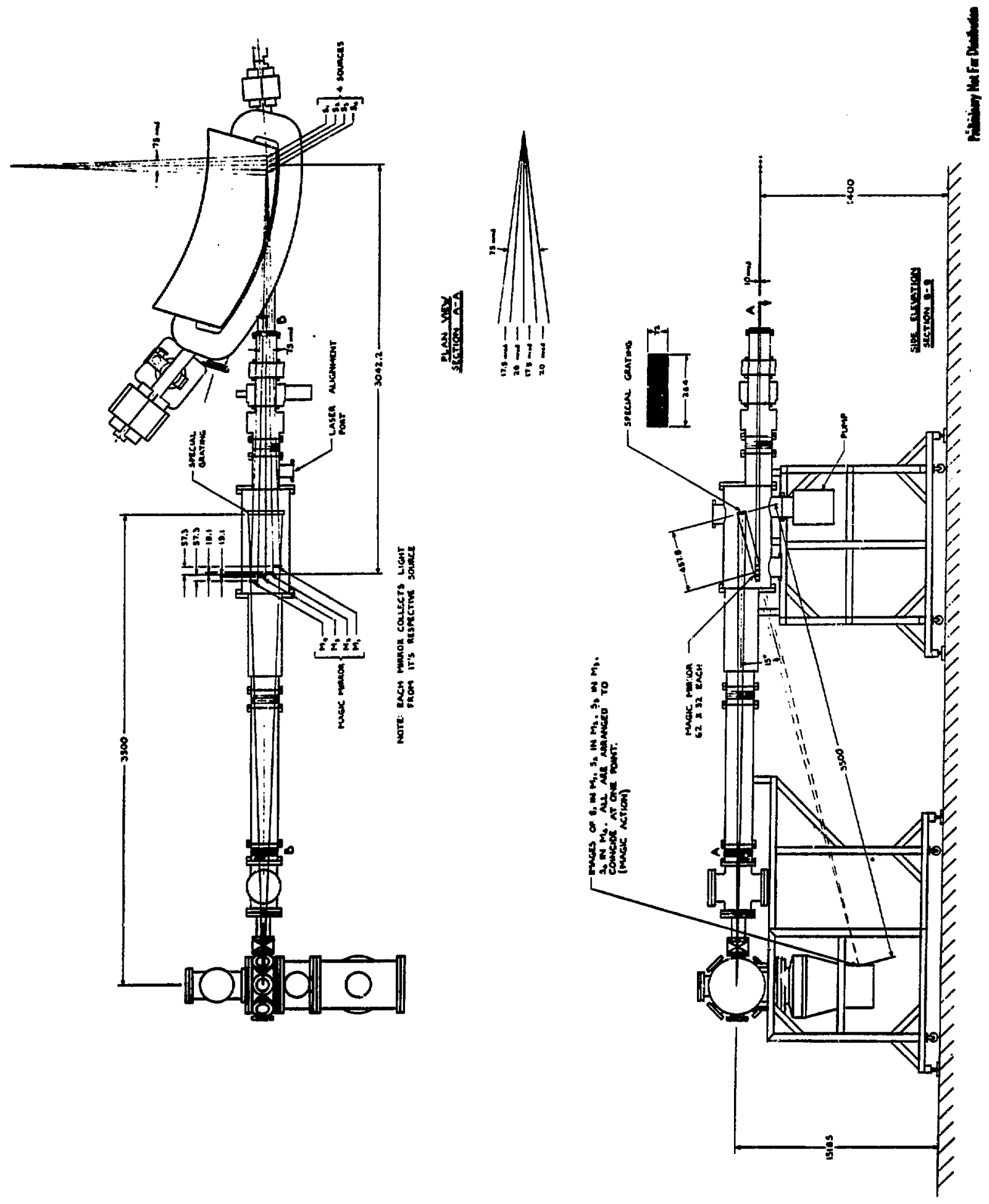

Figure 1 
Table I. Photon fluxes per horizontal mrad at the NSLS uv ring under the following conditions: 1 ampere circulting beam; $R=1.91$ meters; $E=0.7 \mathrm{GeV}$

\begin{tabular}{|c|c|c|c|}
\hline $\begin{array}{l}\text { Banduidith } \\
\lambda(\bar{A})\end{array}$ & $0.1 \%$ & $0.1 \mathrm{eV}$ & $0.1 \AA$ \\
\hline $\begin{array}{r}10 \\
20 \\
30 \\
40 \\
50 \\
60 \\
70 \\
80 \\
90 \\
100 \\
200 \\
300 \\
400 \\
500 \\
600 \\
700 \\
800 \\
900 \\
1000 \\
2000 \\
3000 \\
4000 \\
5000 \\
6000 \\
7000 \\
8000 \\
9000 \\
10000 \\
20000 \\
30000\end{array}$ & $\begin{array}{r}2.07410^{12} \\
7.43610^{12} \\
1.09410^{13} \\
1.29610^{13} \\
1.41510^{13} \\
1.48710^{13} \\
1.53110^{13} \\
1.55710^{13} \\
1.57110^{13} \\
1.57810^{13} \\
1.51210^{13} \\
1.41710^{13} \\
1.33710^{23} \\
1.27210^{13} \\
1.21810^{13} \\
1.7710^{13} \\
1.13210^{13} \\
1.09710^{13} \\
1.06610^{13} \\
8.77410^{12} \\
7.73910^{12} \\
7.08210^{12} \\
6.60610^{12} \\
6.23710^{12} \\
5.94010^{12} \\
5.69310^{12} \\
\mathbf{j} .48210^{12} \\
5.30010^{12} \\
4.23610^{12} \\
3.71710^{12}\end{array}$ & 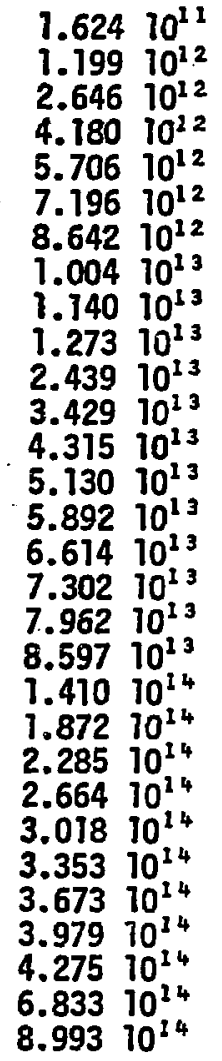 & $\begin{array}{l}2.07010^{13} \\
3.71210^{13} \\
3.63910^{13} \\
3.23410^{13} \\
2.82510^{13} \\
2.47410^{13} \\
2.18310^{13} \\
1.94310^{13} \\
1.74310^{13} \\
1.57510^{13} \\
7.54810^{12} \\
4.71510^{12} \\
3.33810^{12} \\
2.54010^{12} \\
2.02610^{12} \\
1.67010^{12} \\
1.41210^{12} \\
1.21710^{12} \\
1.06410^{12} \\
4.36510^{11} \\
2.57510^{11} \\
1.76810^{11} \\
1.31910^{11} \\
1.03810^{11} \\
8.47110^{10} \\
7.10310^{10} \\
6.08110^{10} \\
5.29110^{10} \\
2.11410^{10} \\
1.23710^{10}\end{array}$ \\
\hline
\end{tabular}


NORMAL INCIDENCE MONOCHROMATOR

\begin{tabular}{|c|c|}
\hline Main Radius (mm) & 3500 \\
\hline Grating SIzE $\left(\mathrm{mm}^{2}\right)$ & $264 \times 72$ \\
\hline Grating Type & SpherIcal \\
\hline mR Collected & $75 \times 10$ \\
\hline Dlspersion $(2400 \mathrm{\ell} / \mathrm{mm})$ & $1.19 \AA / \mathrm{mman}$ \\
\hline Wavelength Range (̊̊) & $300-4000$ \\
\hline
\end{tabular}

RESOLVING POWER AND SPECTRAL RANGE

$\begin{array}{lcc}\begin{array}{l}\text { Groove } \\ \text { Dens1ty } \\ \text { gr/mim }\end{array} & \Delta \lambda(\AA) & \text { Scan Range } \\ 1200 & 0.50 & 0-4000 \\ 2400 & 0.25 & 0-2000 \\ 3600 & 0.16 & 0-1333 \\ 4800 & 0.12 & 0-1000\end{array}$

Table II 


\section{APPARATUS AND UTILITIES}

(J. B. A. Mitche11, Chemistry Department, BNL)

The mandate for the windowless gas phase beamline project at Brookhaven is to provice a versatile apparatus for the study of the interaction of synchrotron radiation with gas phase systems. Th1s apparatus is to be made avallable for use by outside users as well as by in house staff. Since its Inception in 1978, the concept has undergone a number of evolutionary changes culminating in the present design which is described in this report.

The original intention was to provide an experimental chamber which would be large enough and suificiently well equipped to satisfy the projected needs of a wide variety of user applications. In addition, the uitimate goal of the apparatus from the Brookhaven standpoint was to use the synchrotron radiation as a means of identifying the collision products in a crossed beam reactive scattering experiment. This apparatus was Jescribed in a Brookhaven Report (Mitchell and Grover, 1978).

However, as the design of the monochromator proceeded and its predicted output came under closer scrutiny it became clear that a decision on whether to undertake a crossed beam experiment should await actual monochromator experience, considering the uncertainties regarding the avallable photon flux, which is cruclal to success. Therefore the construction of a large, general purpose interaction chamber was postponed, but the provision of a number of Important utilities on a modular basis was retained.

Flgure 2 shows the new apparatus arranged for the study of photoIonization of molecular beams using mass analysis for product detection. It consists of a supersonic nozzle source, a minimal interaction chamber and a cryogentcally cooled beam dump. The system is based on standard 
16.5" Conflat flanges and the main chambers have an internal diameter of 13.75". It is pumped by turbomolecular and cryopumps which comply with the standards of cleanliness imposed by the synchrotron staff. The only exception to this standard is the 16" diffusion pump which is used to evacuate the supersonic nozzle source. This pump is necessary because of the high helium load in the skimmer region but its inclusion is only permitied because of the rjgorous, multi-stage differential pumping between it and the beam line. In general diffusion pumps will not be acceptable for windowiess experiments on the synchrotron.

Figure 3 shows an end-on view of the apparatus. The synchrotron radiation enters the interaction chamber through a differentially pumped image slit. This slit will be fitted with a fast acting ( 10 msec) shutter which can be closed tn the event of a pressure rise or buildup of hydrocarbon contamination in the chamber. The interaction chamber has eight 4" ID side arms which allow access for pumping, quadrupole mass spectrometer, photon detector, etc.

Figure 1 shows the apparatus attached to the synchrotron beanline together with the monochromator which has already been described earlier in this report.

It should be emphasized that the diagrams shown here represent only one possible configuration of this apparatus. Standard modular components have been intentionaily provided to accomodate rearrangements to suit the particular needs of the interested user. In some cases the vacuum chambers supplied will not be suitable and in this event it is suggested that the user supply his own chamber. Such a user will be iree to use the utilities such as pumps, electronics, etc. which are part of the windowless gas phase package. A list of these utilities is given in Table I. In Table II the costs of the various components comprising the windowless gas phase.line are outlined. 
Table III gives a breakdown of the individual vacuum components. It can be seen that in fact the vacuum chambers represent a small fraction of the total cost of the project and so should not represent a major deterrent to the dedicated user.

In addition to the items mentioned in the above tables, many users will want to supply their own ancillary equipment, e.g. electron spectrometers, flat flame burners, etc. It is important to realize that all such equipment must meet the standards compatible with the vacuum specifications laid down by the synchrotron design group. Only ultrahigh vacuum compatible materials wt.ll be acceptable for fabrication purposes. This entalls the use of stainless steel, copper, ceramic, and to a limited extent glass for construction purposes. Brass, aluminum, Teflon, and nylon are not considered acceptable because of thelr outgassing properties. In addition all vacuum chambers must be fitted with all metal seals. No elastomer o-rings will be allowed. UHV chanbers may either be purchased from the varinus corpanies who spectalize in their construction or alternatively they may be constructed at the user's own institution if sufficlent workshop facilities are available. The chambers supplied as part of the windowless gas phase beam line package were constructed on-gite at Brookhaven although all the flanges were purchased outside. Table IV lists some of the specifications for the construction of chambers laid down by the synchrotron design staff. Regarding the possibility of the user supplying some of his own pumps It must be stressed that these also must be ultrahigh vacuum compatIble. Thus turbopumps, cryopumps, titanfum pumps, fon pumps, and well trapped rotary pumps are allowed whilst diffusion pumps are almost certainly excluded. Furthermore it has; been specified that all pumps which use ofl for their operation (including turbopimps and rotary pumps) should be filled 
with Fomblin ofl. This is a polyfluoroether fluid which has the unique property of vaporizing upon irradiation. This should offer a great advantage over silicone and polyphenyl ether oils which tend to form a solid polymer deposit under the action of energetic radiation. This is a serious problem in synchrotrons due to the deterforation of optical surfaces through oil contamination. Fomblin is available from Edwards High Vacuum, Ltd. in two grades, Y18/8 which is used for turbopumps and diffusion pumps and Y16 for rotary pumps.

Finally, it is suggested that potential users should contact the authors prior to constructing any apparatus to ensure that 1 will be compatible with this project.

\section{Reference}

J. B. A. Mitche11 and J. R. Grover, BNL Report No. 50920, 1978 


\section{CAPTIONS}

FIGURE 2. (SIDE VIEW)

A. NOZZLE CHAMBER

B. COLLIMATOR CHAMBER

C. INTERACTION CHAMBER

D. MOLECULAR BEAM DUMP

E. QUADRUPOLE MASS SPECTROMETER

F. CRYOPUMP AND COLD SHIEID ASSEMBLY

G. DIFFUSION PUMP

H. TURBOMOLECULAR PUMP

FIGURE 3. (END ON VIEW)

A. BUFFER CHAMRER

B. Gate VALVE

C. INTERACTION CHAMBER

D. QUADRUPOLE MASS SPECIROMETER

E. CRYOPUNP AND COLD SHIEID ASSEMBLY

F. LIQUID NITROGEN TRAP

G. PHOTON DETECTOR

H. TURBOMOLECULAR PUMP

J. PHOTON BEAM 


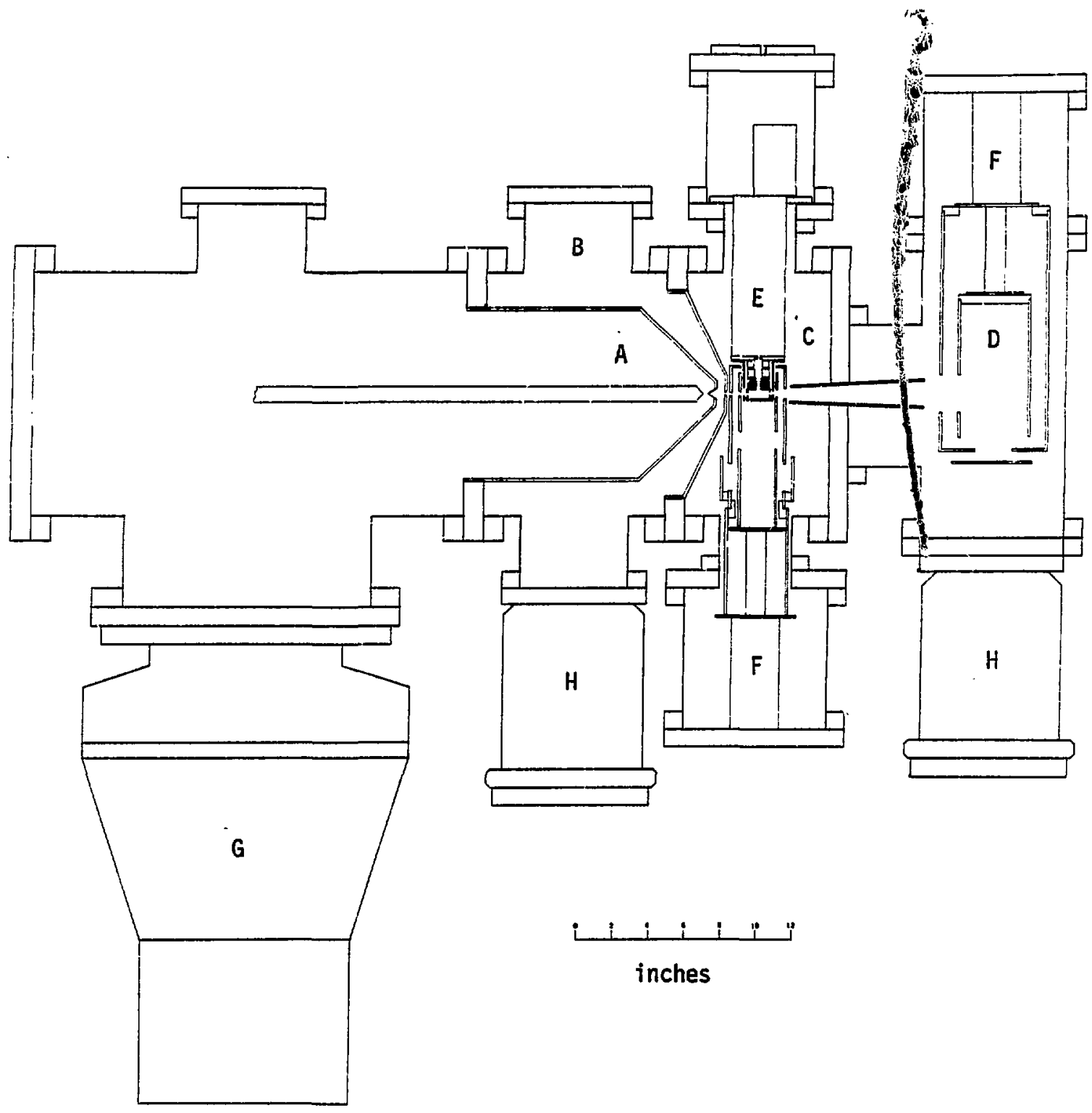

Figure 2 


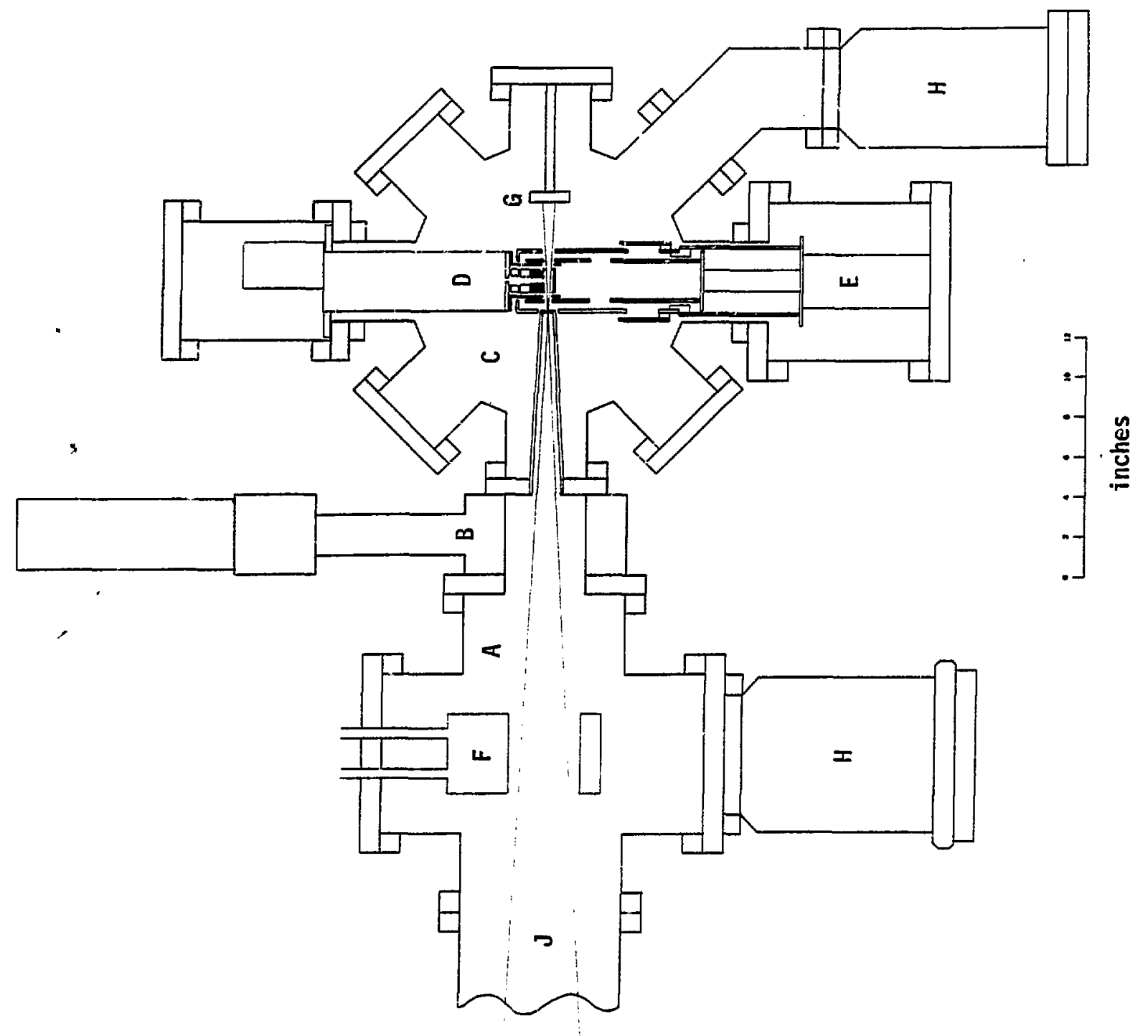

Figure 3 


\section{WINDOHLESS GAS PHASE BEAMLINE PROJECT . \\ Utilities List}

\begin{tabular}{|c|c|c|c|c|}
\hline ITEM & COMPORENT & QTY. & MANUFACTURER & REMARKS \\
\hline 1. & UHV Chambers & 4 & $\begin{array}{l}\text { BNL Central } \\
\text { Workshops }\end{array}$ & $\begin{array}{l}\text { See Accompanying } \\
\text { Drawings }\end{array}$ \\
\hline 2. & $\begin{array}{l}4501 \mathrm{~s}^{-1} \\
\text { Turbomolecular } \\
\text { Pumps. 8" OD } \\
\text { Conflat Flanges } \\
\text { on input }\end{array}$ & 2 & $\begin{array}{l}\text { Leybold- } \\
\text { Heraeus or } \\
\text { Blazers }\end{array}$ & Vertical Mounting \\
\hline 3. & $\begin{array}{l}220 \mathrm{ls}^{-1} \\
\text { Turbumolecular } \\
\text { Pump. } 6^{n} \text { OD } \\
\text { Conflat Flange } \\
\text { on input }\end{array}$ & 1 & $\begin{array}{l}\text { Leybold- } \\
\text { Heraeus or } \\
\text { Biazers }\end{array}$ & $\begin{array}{l}\text { Vertical Hounting } \\
\begin{array}{l}. \\
\quad \therefore\end{array}\end{array}$ \\
\hline 4. & $\begin{array}{l}\text { Cryopumps } \\
4 \text { Watt Closed } \\
\text { Hel ium Refrigerated } \\
\text { Cold Heads }\end{array}$ & 2 & CTI Model 350 & $\begin{array}{l}\text { Cryosurfaces. } \\
\text { Supptied by iser }\end{array}$ \\
\hline 5. & $\begin{array}{l}\text { Supersonic Nozzle } \\
\text { Beam Apparatus + } \\
\text { Beam Dump } \\
\text { Interchangeab?e } \\
\text { Nozzles, Helium } \\
\text { Seeding Capability } \\
\text { Interfaced to } 16.5 " \\
\text { Conflat Flange }\end{array}$ & 1 & $\begin{array}{l}\text { BNL Central } \\
\text { Workshops }\end{array}$ & $\begin{array}{l}10,0001 s^{-1} \\
\text { Pumping Capacity for } \\
\text { Helium }\end{array}$ \\
\hline 6. & $\begin{array}{l}\text { Monuchromator } \\
\text { Exit S1 it Assembly } \\
\text { Differentially } \\
\text { Pumped } \\
\text { Fast Closing Shutter } \\
\text { ( } 10 \text { msec) } \\
\text { Mounted on 6" oD } \\
\text { Conflat Flange }\end{array}$ & . & $\begin{array}{c}\text { BNL Central } \\
\text { Horkshops }\end{array}$ & . \\
\hline 7. & Computer & 1 & $\begin{array}{l}\text { Under Decision by } \\
\text { NSLS Staff }\end{array}$ & $\begin{array}{l}\text { Used for Monochromator } \\
\text { Contro. Can also be } \\
\text { used for data collection. }\end{array}$ \\
\hline 8. & $\begin{array}{l}\text { Quadrupole Mass } \\
\text { Spectrometer System } \\
1-350 \text { AMU } 3.0 M H z \\
\text { and } 1.25 \mathrm{MHz} \\
\text { R.F. Heads }\end{array}$ & 1 & $\begin{array}{l}\text { Extranuclear } \\
\text { Labs, Inc. } \\
\text { Modei 7-324-9 }\end{array}$ & \\
\hline 9. & Fast Counting System & & Ortec & $\begin{array}{l}\text { Comprises Models 9315, } \\
\text { T105/N, 454,719, } \\
401 A / 402 A, 459,9301\end{array}$ \\
\hline
\end{tabular}


TABLE II. COST OF CONPONENTS

1. Front End

$\$ 50,000$

2. Monochromator and Computer (Estimated)

$\$ 80,000$

3. Pumps

$\$ 60,000$

4. Quadrupole Mass Spectrometer \& Fast Counting

$\$ 21,000$

5. Adapter Fianges

$\$ 5,000$

TABLE III. BREAKDOWN OF VACUUM CHAMBER COSTS

Interaction Chamber

$\$ 3,200$

Collimator Chamber

$\$ 2,620$

Nozzle Chamber

$\$ 2,885$

Beam Dump

$\$ 1,775$

Buffer Chamber

$\$ 1,480$

TABLE IV. NOTES FOR MACHINING

1. These are ultra-high vacuum parts.

2. Use of sulphur bearing oils and abrasives is prohibited

3. Use only CIMCOOL, KOOLMIST No. 77, Mobile Cut-max, MHssile Lube No. 5 or NSLS approved equal for lubricant when machining.

4. Leak test with a helium mass spectrometer leak detector. Total leak rate not to exceed $2 \times 10^{-10} \mathrm{std} \mathrm{cc} / \mathrm{sec} \mathrm{He}$. 


\section{PROPOSED EXPERTMENTS}

This section is a collection of short contributions by the individual members of the Participating Reseacch Team, outlining the experimental directions they feel they will most probabiy wish to pursue, at this early stage in planning. 
H. A. Chupka

Department of Chemistry

Yale UnIversity

My Interests stem from my work using laboratory light sources and the expanded posstbllitles afforded by the NSLS are rost exciting. These are summarlzed as follows:

1. Photolonization mass spectrometry. Although this work has been extensively and very rewardingly exploited with laboratory light sources in recent years, I am very optimistic that many experiments now impractical with lab sources will become feastble with the storage ring source. I have In wind such experiments as (a) the very complete photophysical characterfzation of the decay of exclted molecules, simultaneous measurement of Ionfation, fluorescence and fragmentation, preferably In coincidence; (b) Ion-molecule reactions with more precise control over reactant energies than previously possible.

2. Photoelectron spectroscopy with varlable wavelengths. This capability should Include provision for work with supersontc (cooled) beams and high temperature vapors as well as ordinary gases and should also include fluorescence and mass analytic capabllity. The higher intensity and unique time structure of the radiation offers exciting possibllities for study of weak and short lived fluorescences. The general problem of detailed analysis of photoelectron spectra can be addressed more powerfully with this new tool.

3. Photochemistry in the UV and vacuum UV. Much photochemistry done wIth Iine sources (for Intensity reasons) can be attacked more extensively with the intense varlable wavelength source the storage ring offers. I would like to try some such experfments using matrix-1solated molecules initially to minimize the gas contamination problem. 
M. O. Krause

Chemistry Division

Oak Ridge National Laboratory

The research interests of the ORNL chemistry group lie primarily in the area of angle-resolved photcelectron spectrometry in the gas phase. The photon energies of interest range from about $15 \mathrm{eV}$ to above $1 \mathrm{keV}$, but the range of most immediate interest covers 20 to $300 \mathrm{eV}$. Resolution needed at the beginning varies from about $0.1 \mathrm{eV}$ at $20 \mathrm{eV}$ to about $2 \mathrm{eV}$ above $500 \mathrm{eV}$, but should be improved in later phases successively to $10 \mathrm{meV}$ and $0.1 \mathrm{eV}$, respectively. Partial (subshell, vibrational) photolonization cross sections and angular distribution parameters will be measured in atoms and molecules, but other quantities such as binding energies (single and multiple excitation), level widths, Auger electron energies and Intensitles will also be obtalned. Such measurements will improve our understanding, and advance the theory of the electronic structure and dynamics of atoms and molecules ${ }^{*}$ and w11 provide a reliable underoinning for electronic solid state phenomena. ${ }^{\star *}$ We expect to study, Inter alla, vibronic-electronic interactions in molecules (breakdown of Franck-Condon Princlple) via shape resonances and autolonization processes, anisotropic and final lonic state interactions in open shell atoms and in molecules via angular distribution measurements, initlal and final state correlation effects vla photoelectron energy and subshell cross section determinations, and threshold effects, such as post collision interactions, by way of Auger electron spectrometry.

\footnotetext{
*See, for example, M. O. Krause In Synchrotron Radlation Research, edited by S. Doniach and H. Winick, Plenum Press $(1979 / 80)$, Ch. 3 .

** See, for example, B. Sonntag, J. Phys. (Paris) 39, C4-9 (1978).
} 
J. P. Grover and J. B. A. Mitchell

Department of Chemistry

Brookhaven NatIonal Laboratory

We are considering two lines of investigation using the windowless

gas phase beamline on the NSLS; both w1ll exploit a nozzle beam apparatus.

1. VUV photolonization spectroscopy of cooled free radicals and small reactlve molecules.

2. Formation energetics and reactivities of clusters.

1. Free Radicals and Reactive Molecules

Thls work is motivated by plans to accumulate data and develop techniques for the analysis of mixtures of tranglent specles arising from chemical reactions, We are especially interested in performing such analysis under single-colliston conditions both to Identify spectes in mixtures and to neasure distributions of excitation energy.

Inftlally we plan to prepare molecular beams containing these spectes using fiow tubes, diffusion flames and other approprlate techniques. We shall endeavor to seed these species into hellum followed by a subsequent nozzle expansion to achieve strong cooling. The measurement of their photolonization excitation functions will provide a catalogue of reference spectra, and will also supply a low temperature reference on which to base estimates of excitation energy when they are observed as reaction products. At a later stage we plan to Incorporate a laser to allow us to excite the cooled molecules and radicals to known exclted states. Many of the specles we are planning to study have not previously been subjected to photolonization spectroscopy because of the difficulty of producing them In high concentrations, a problem that will be greatly alleviated by the high 
available flux of tunable VUV at the NSLS. Examples are $\mathrm{CH}, \mathrm{CH}_{2}, \mathrm{CH}_{3}$, $\mathrm{C}_{2} \mathrm{H}$. These molecules are of spectal interest to flame studies and to intergtellar chemistry. In addition it should be of considerable theoretical interest to directly verify the energy spacings of the

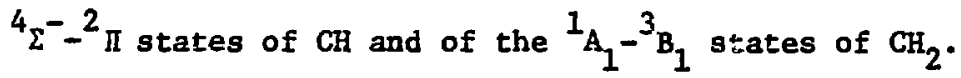

\section{Clusters}

Beams cf clusters can be made by condensation during nozzle expansions, or by seeding with preformed clusters before nozzle expansions. Hydrogen bonding has a profound effect on clustering, a phenomenon of great theoretical as well as practical interest. We are particularly Interested in the atmospheric and blological aspects. An understanding of water nucleation and water cluster energet:ics is of crucial importance to atmospheric models, especially with respect to the 1mportant problem of global solar energy gain and loss and its relationshlp to atmospherfc pollutants, trace components, and the growing $\mathrm{CO}_{2}$ concentration in the troposphere.

It has recently proved possible to make beams of purine-pyrimidine pairs and this opens up the very interesting prospect of carrying cut VUV photolonization spectroscopy on these substances. Experiments with associated parent molecules or substituted derivatives and with added water molecules should lead to substantial contributions to understanding the energetic relationships underlying the hereditary material of living organtsms.

Clusters of more refractory materfals, such as carbon or the transition metals will be examined. Investigations of carbon clusters will lend insight into soot formation. Studies of transition metal clusters will foster an improved understanding of catalysis. 


$$
\text { C. }-\mathrm{Y} \text {. Ng }
$$

Ames Laboratory and Department of Chemistry, Iowa State University, Ames, IA 50011

and

\section{J. Berkowitz}

Physics Division, Argonne National Laboratory, Argonne, IL 60439

We plan to pursue two general avenues of investigation which utilize sove of the spectal features of synchrotron radiation and the supersonic expansion technique.

(1) Studies of the photoionization and fragmentation behavior of simple molecules, dimers and clusters.

Inftially, a simple (Knudsen) molecular beam will be crossed by dispersed VUV radiation and the ionic products analyzed by a quadrupole mass spectrometer. Particular emphasis will be placed upon the erergy region $>20 \mathrm{eV}, 1 . e$. beyond the usual laboratory domain. A second set of experiments covering the same wavelength range will detect photoions and photoelectrons formed concomitantly, the former using a time-of-flight (TOF) mass spectrometer and the latter a threshold photoelectron detector. The photoelectron measurement will select the state of the molecular fon, the TOF measurement vill provide mass and kinetic energy information. We hope to extend these measurements to the region of innter shell excitation, where information is currently sparse. 
After the simple molecular species has been well characterized by the above techniques, we plan to apply them to the products of supersonic expansion, and compare the behavior of dimers and larger clusters with the monomeric molecules.

(2) Studies of ion-molecule reactions in selected states using the photoelectron-photoion coincidence technique.

The experimental arrangement will be similar to that used in (1). In some experiments, a simple gas cell operated at higher pressure will permit ton-molecule reactions to be observed. The product ions will be measured in coincidence with the threshold photoelectrons, thereby enabling us to examine internal energy effects. The eiffect of an eiectric field across the gas cell wili provicie some Information about kinetic energy effects. If possible, we plan to pursue these experiments by separating the lonization and reaction zones. One of these may now be a supersonic jet, thereby making possible the study of cluster molecules or clister ions. 


\author{
James M. Farrar \\ University of Rochester
}

We are proposing three gener: : areas of gas phase kinetics which we wish to pursue at the NSLS WGPBL facility. We describe these areas below along with our specific experimental requirements.

1. Ion-molecule reactions induced in van der Waals molecules. Van der Waals clusters, produced by supersonic expansion of a precursor gas or gas mixture have recently been exploited in conjunction with photoionization mass spectrometry as a tool to study proton transf $r$ thermochemistry ${ }^{l}$ and vibrational predissociation. $^{2}$ We wish to prepare clusters, photoionize one molecule in the cluster state-selectively, and examine the ensuing vibrationally induced zero kinetic energy ionmolecule reactions. The recent work on $\left(C_{2} \mathrm{H}_{4}\right)_{2}$ by Lee ${ }^{3}$ demonstrates the kind of fine control of internal energy which one can achieve. Mixed dimers such as $\mathrm{N}_{2} \cdot \mathrm{O}_{2}, \mathrm{CO} \cdot \mathrm{N}_{2}, \mathrm{CO} \cdot \mathrm{O}_{2}$ and $\mathrm{CO} \cdot \mathrm{CO}_{2} \mathrm{Wlit}$ provide particularly interesting cases where either species can be ionized selectively. Mass spectral detection of reaction products as a function of wavelength will be required in these experiments.

2. Dissociative photoionization of molecules.

A measurement of the kinetic energy release when a molecule $A B$ dissociates into $A+B^{+}+e^{-}$yields great insight into 
the potential surfaces involved in the dissociation. Particularly interesting dynamical questions arise when the dissociated molecule is a polyatomic; in particular, the dissociation of triatomics can be quite illuminating when internal energies of molecular photofragments are determined. The use of seeded molecular beams which accelerate heavy molecules when expanded with a light carrier gas improves kinematics dramatically and allows one to infer internal energy from translational energy spectra. We anticipate photon resolution of $\sim 0.3 \AA$; we will perform these experiments with a seeded beam source, detecting ionic photofragments via electrostatic energy analysis and quadrupole mass spectrometry. Molecules for study are quite numerous and we expect $\mathrm{N}_{2} \mathrm{O}, \mathrm{HCN}, \mathrm{CO}_{2}$, OCS, $\mathrm{H}_{2} \mathrm{O}, \mathrm{O}_{3}, \mathrm{CH}_{3} \mathrm{Cl}, \mathrm{CH}_{3} \mathrm{Br}$, and $\mathrm{CH}_{3} \mathrm{I}$ to be among the first we study.

3. Photodissociation of neutral molecules to neutral photofragments.

The basic questions we wish to ask are similar to those in the previous experiment. The analysis of neutral photofragments will be achieved in two ways: we expect to observe fluorescence from many molecules creating electronically excited photofragments. The polarization of the fluorescence will be of value in elucidating photofragment angular distributions and possible angular momentum polarization.

Detection of ground state photofragments will be by dye laser induced fluorescence. We expect therefore to be able 
to get a fairly complete picture of molecular dissociation for simple systems.

Recent theoretical work on linear symmetric triatomics 4,5 suggests that a number of interesting questions can be probed by examining total photodissociation cross sections. In particular, the total cross section for $\mathrm{XY}_{2}$ dissociation may be structured even though the dissociation is direct rather than predissociative. We wish to probe this and related questions on systems such as $\mathrm{CO}_{2}$ and $\mathrm{Cs}_{2}$, extending these studies to non-linear $\mathrm{XY}_{2}$ species such as $\mathrm{O}_{3}, \mathrm{SO}_{2}, \mathrm{H}_{2} \mathrm{O}$, and $\mathrm{NO}_{2}$.

\section{References}

1. C. Y. Ng et al., J. Chem. Phys. 67, 4235 (1977).

2. T. Hirooka et al., to be published in J. Chem. Phys.

3. S. T. Ceyer et al., J. Chem. Phys. 70, 2138 (1979).

4. R. T. Pack, J. Chem. Phys. 65, 4765 (1976).

5. E. J. Heller, J. Chem. Phys. 68,3891 (1978). 


\author{
R. B. Klemm \\ Department of Energy and Environment \\ Brookhaven National Laboratory \\ and \\ D. J. Seery \\ United Technologies Research Center
}

1. BNL

A design for a flame probe experiment that will employ molecular beam sampling and photolonization mass spectrometry is shown in two aspects in Figs. FI and F2. This experiment will utilize, and depend upon, the essential components of the apparatus described in detal? in section IV (Apparatus and Utilities). As planned, this experiment will be operated by the DEE/Chem. Sc1. DIv. Alternative Fuels Combustion Program in collaboration with Drs. D. J. Seery and M. F. Zabielski of United Technologies Research Center and Drs. J. Peeters and C. VInckler of the UnIversity of Leuven, Belgium (see attached letter).

Basically, this experiment is designed to identify radical and intermedlate specles that exist in flames using various fuels, oxidants, and diluent gases. The imediate purpose of the work is to gain information of reaction mechanisms and pathways. The burner used in this work will be of the cooled, porous plug, flat flame design. The transport properties of the gases in the flame in this type of burner are reasonably well defined. ${ }^{1}$ The flame is also stabie over a wide range of air-fuel ratio, and thus maximum flame temperature ${ }^{2}$; and the radial profile of $t$, flame is very uniform. $^{3}$ A windowless beam Iine is required for this work to obtain 
sufficiently energetic photons to ionize a majority of radicals and molecules of interest (see Table F-I).

The results of this experiment are expected to yleld information in "

the mechanisty of oxidation and pollutant formation reactions, to identify the most imfortant reactions (via sensitivity analysis) and to obtain estimates of bimolecular rate constants at high temperatures by computer fitting of the experimental species profiles using a flame model that includes reaction kinetics. In addition, it may be possible to obtain Information on the vibronic excitation in the flame species by utilizing the tunability of a windowless gas phase beam line on the NSLS. In principle, this would be accomplished by observing step changes in the signal of a certain spectes (fixed m/e) while scanning the wavelength range from threshold for that spectes toward lower energles. Excess vibroilc energy in diatomic molecules can recuce the ionfzation energy and thus the effective Ionization potential. Wavelength resolution of about $1 \AA$ in the $1000 \AA$ region is expected to be suffictent to separate the energy levels In this Investigation.

2. UTRC

A long range program is under way to elucidate the mechanism of fuel nitrogen conversion to $\mathrm{NO}_{\mathrm{x}}$. To thls end, composition profiles are being measured In low pressure methane oxygen flames to which small amounts of nitrogenous species have been added. Particular emphasis will be placed on determining the relationshIp betw-en the intermediates $\mathrm{HCN}$ and $\mathrm{NH}_{3}$ in the NO formation process. While the major stable specles can be readily measured, there are serfous difficulties in making accurate measurements of import-2nt radical species such as $\mathrm{N}, \mathrm{NH}, \mathrm{C}, \mathrm{CH}$, and $\mathrm{C}_{2}$. Both $\mathrm{N}$ and $\mathrm{NH}$ are Involved in the mechantsms of 
formation and decay of NO, while the carbon spectes have been suggested as the crucial reactants in the formation of "prompt $\mathrm{NO}^{\prime}$ from $\mathrm{N}_{2}$.

A new mass spectrcmeter has been ordered and attempts will b: made to measure these species using the appearance potential technique. If this technique is not sensitive enough to obtain the necessary data, then photoIonization-mass spectrometry using the WGPBL will be attempted. The Ionfzation potentials for many of these radical species are beyond the practical limit for LiF thus making the windowless experiment the only practical approach.

\section{References}

1. C. P. Fenimore and G. W. Jones, Tenth Symposium (Int'1) on Combustion, The Combustion Institute, p. 489 (1965).

2. J. C. Biordi, C. P. Lazarra, and J. F. Papp, Fourteenth Symposium (Int'1) on Combustion, The Combustion Institute, p. 367 (1973).

3. D. J. Seery and M. F. Zabielsk1, paper \$77-45 presented at the 1977

Fal1 Meeting-Western States Section - The Combustion Institute, Oct. 1977, Stanford, CA. 


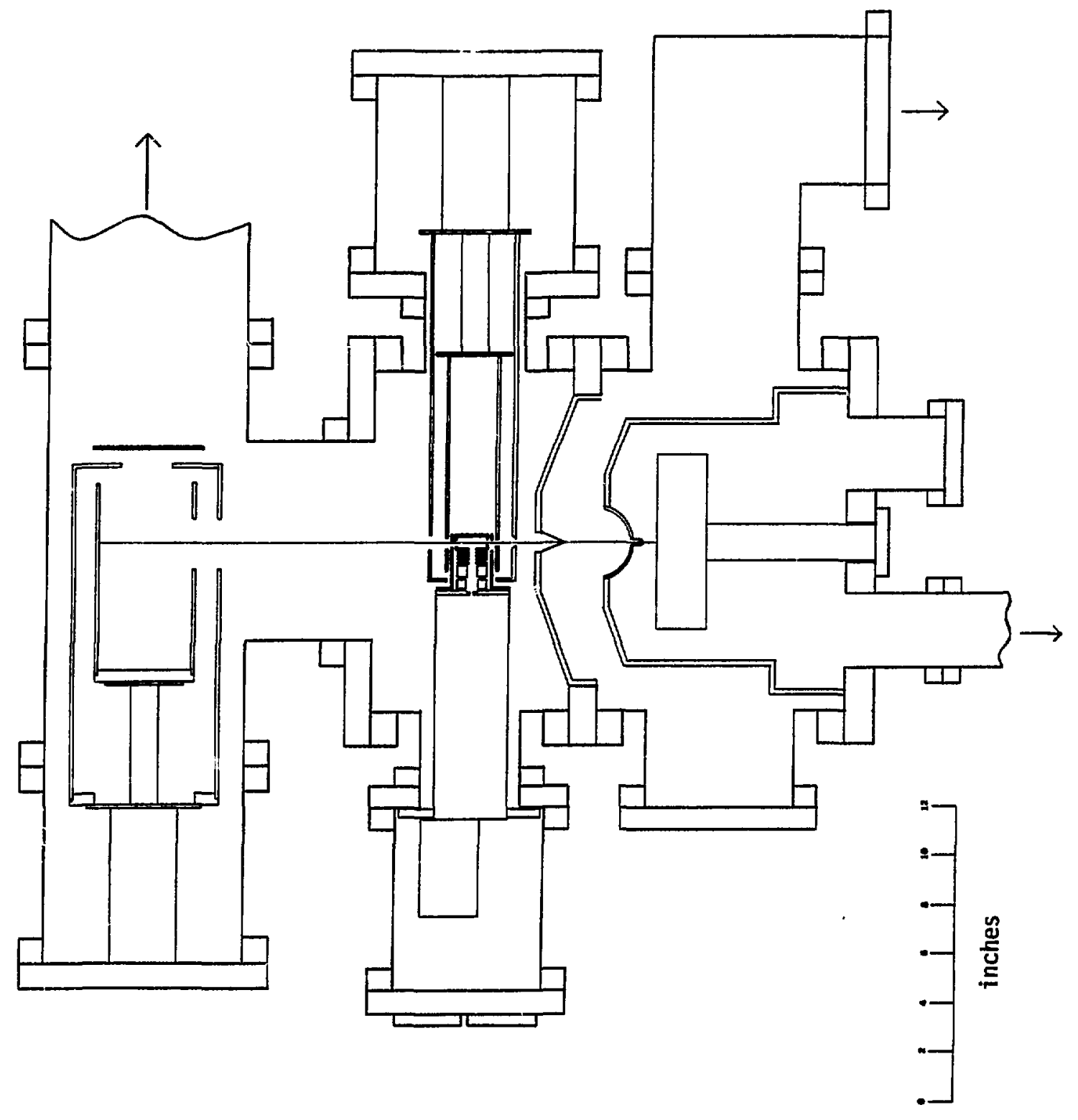

Figure FI 


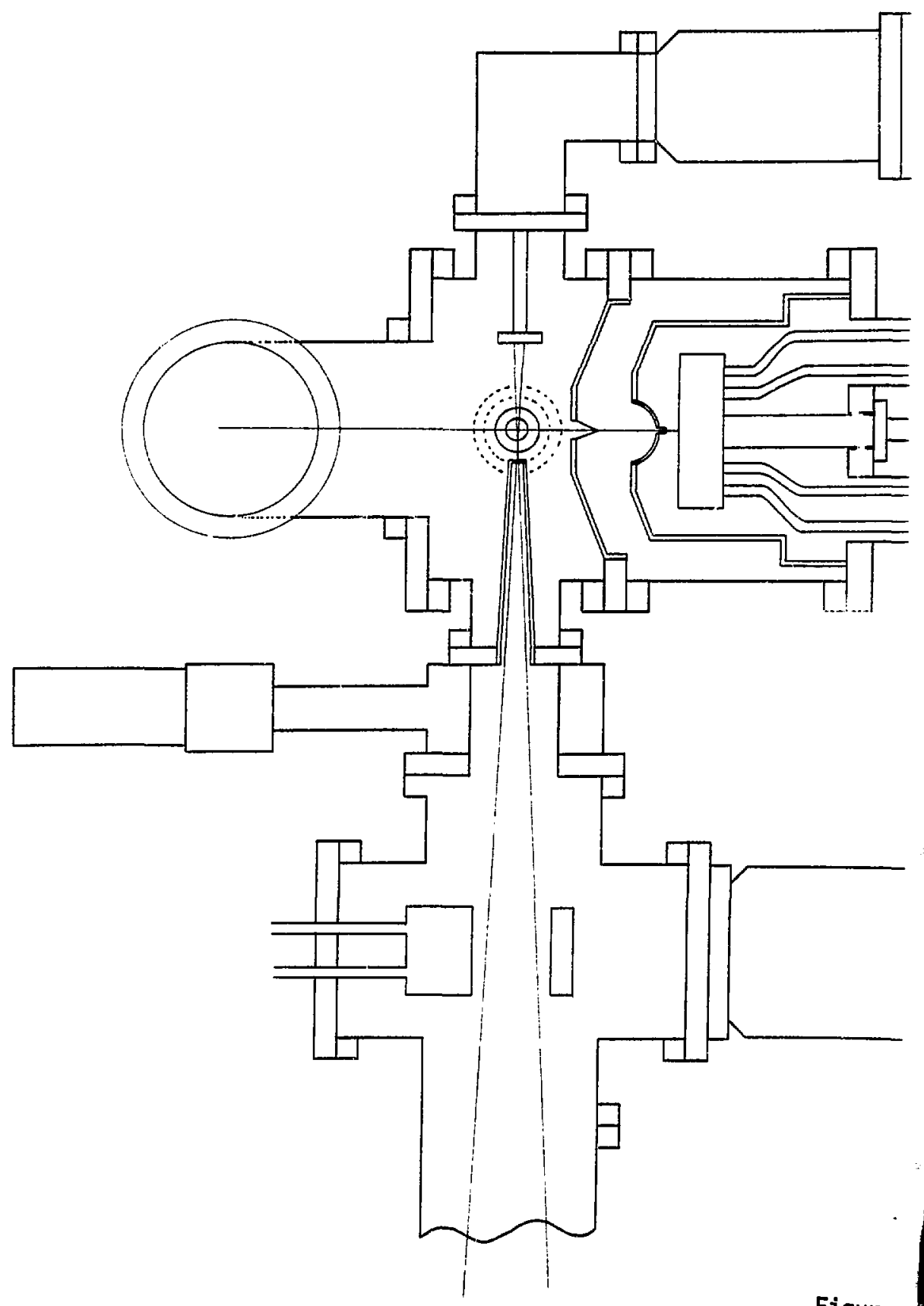

Figure 
Table F-1

Ionization Potentials of Some Important Flame Species ${ }^{a}$

\begin{tabular}{|c|c|c|c|c|c|}
\hline Spectes & I.P. & Spectes & $\underline{I . P .}$ & Species & I.P. \\
\hline H & $13.5^{*}$ & $\mathrm{HO}_{2}$ & $11.5^{\star \star}$ & $\mathrm{HCN}$ & 13.8 * \\
\hline \multirow[t]{2}{*}{$\mathrm{H}_{2}$} & $15.4^{*}$ & $\mathrm{H}_{2} \mathrm{O}$ & $12.6^{*}$ & $(\mathrm{CN})_{2}$ & 13.6 * \\
\hline & & $\mathrm{B}_{2} \mathrm{O}_{2}$ & $11.1^{* \star}$ & No & 9.25 \\
\hline C & $11.3^{* *}$ & Co & $14.1^{*}$ & $\mathrm{NO}_{2}$ & 9.8 \\
\hline$c_{2}$ & $12.3^{*}$ & $\mathrm{CO}_{2}$ & $13.7^{*}$ & $\mathrm{~N}_{2} \mathrm{O}$ & $12.9^{*}$ \\
\hline $\mathrm{CH}$ & $11.1^{* *}$ & $\mathrm{HCO}$ & 9.9 & & \\
\hline $\mathrm{CH}_{2}$ & 10.7 & $\mathrm{H}_{2} \mathrm{CO}$ & 10.9 & $\mathbf{s}$ & 10.4 \\
\hline $\mathrm{CH}_{3}$ & 9.8 & $\mathrm{CH}_{3} \mathrm{O}$ & 7.8 & $s_{2}$ & 9.6 \\
\hline $\mathrm{CH}_{4}$ & $12.7^{*}$ & $\mathrm{CH}_{3} \mathrm{OH}$ & 10.8 & HS & 10.5 \\
\hline $\mathrm{C}_{2} \mathrm{H}_{2}$ & $11.4^{* *}$ & $\mathrm{CH}_{3} \mathrm{CHO}$ & 10.2 & $\mathrm{H}_{2} \mathrm{~S}$ & 10.4 \\
\hline $\mathrm{C}_{2} \mathrm{~B}_{4}$ & 10.45 & & & cs & $11.9^{*}$ \\
\hline $\mathrm{C}_{2} \mathrm{~B}_{5}$ & 8.5 & $\mathrm{~N}$ & $14.5^{*}$ & $\mathrm{cs}_{2}$ & 10.1 \\
\hline \multirow[t]{2}{*}{$\mathrm{C}_{2} \mathrm{H}_{6}$} & $11.6^{*}$ & $\mathrm{~N}_{2}$ & $15.6^{*}$ & ocs & 1]. $.2^{* *}$ \\
\hline & & NH & $13.1^{*}$ & so & 10.6 \\
\hline 0 & $13.62^{*}$ & $\mathrm{NH}_{2}$ & $11.4^{\star *}$ & $\mathrm{SO}_{2}$ & $12.4^{*}$ \\
\hline $\mathrm{O}_{2}$ & $12.01^{*}$ & $\mathrm{NH}_{3}$ & 10.2 & & \\
\hline$o_{3}$ & $12.3^{*}$ & $\mathrm{~N}_{2} \mathrm{H}_{4}$ & 9 & & \\
\hline $\mathrm{OH}$ & $13.2^{*}$ & $\mathrm{CN}$ & $14.5^{*}$ & & \\
\hline
\end{tabular}

a Taken from NSRDS-NBS-26 (Ionization Potentials, Appearance Potentials, and Heats of Formation of Gaseous Positive Ions, 1969).

The effective short wavelength cutoff for LIF - $1080 \AA$ - corresponds to $11.5 \mathrm{eV}$. With this restriction, species with an IP less than about $(* *)$ $11.0 \mathrm{eV}$ will be lonized; those with an IP between $11.0 \mathrm{eV}$ and $11.5 \mathrm{eV}$ w111 be lonized weakly; and those with an IP greater than $11.5 \mathrm{eV}(*)$ w11l not be lonized. 
Departement Schelkunde

LABORATORIUM VOOR ANALYTISCHE EN ANORGANISCHE SCHEIKUNDE

Dir.: S. Oe Jaegere, Dr. Sc., Geeggr. H.O.

Gewoon Hoogleraar

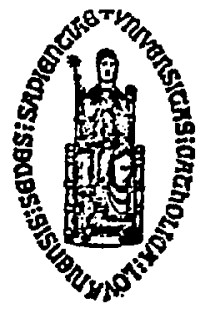

Uw kenmerk

Dear Dr. Klemm,

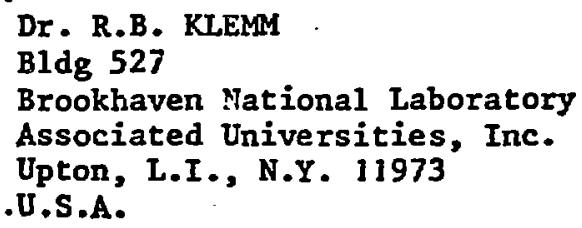

Uw brief van

3030 Heverlee

Celestijnenlaan $200 \mathrm{~F}$

27/4/79

April 27,1979

I greatly appreciate your proposal to collaborate with your group on the planned PIMS study of flames and elementary reactions using the National Synchrotron Light Source at Brookhaven.

Surely, the high intensity in the VUV range and especially the tunability of the NSLS makes this Source an ideal instrument for a PIMS investigation of the concentrations and internal energy states of internediates and products in flame's as well as in low temperature reactors.

I have given your proposal considerable thought and I would be quite interested to collaborate with your group on this project. However, a major obstacle is that it would be very difficult for me to contribute funds to the program.

On the other hand, more limited forms of collaboration might perhaps be accep". table to you. Our group in Leuven could contribute in three ways: first, we could advice gou on the design and construction of a suitable sampling system, secondly, we could suggest specific research topics and thirdly, Dr. C. Vinckier - whom jou met in Leeds last summer - could help out with the actual experiments. 
I suppose you intend to apply molecular beam sampling, beam modulation and phase sensitive detection. As you certainly realize, there might arise a few problems in connection with sampling. In order to ensure that the distribution of internal energy states is not altered, wall and gas phase collisions during sampling should be minimized. Also, one must make sure that the in-phase component of the periodic variation of the randomized gas pressure in the ion source is small compared to the beam particle density. Another matter of importance, especially for flame work, is the angle of the sampling probe. A blunt probe with too large an angle will disturb the flame appreciably whereas too small an angle results in wall and gas phase colzisions and hence beam intensity loss. We found a 40 to 50 degree angle to be a reasonable compromise for flame probing.

As to possible direct participation of our group, Dr. Chris Vinckier told me he would consider coming to Brookhaven for a period of maybe six months and assist with the experimental work. Dr. Vinckier took his $\mathrm{Ph}$. $\mathrm{D}$. in 69 at the Uniyersity of Leuven; he has quite some experience in flame and flow tube research. He stayed already in the U.S.A. for two years whare he did PIMS work with Professor Bayes at U.C.L.A. He is currently a "Qualified Researcher" of the Belgian National Science Foundation and he would stiil be salaried by this foundation while doing research abroad..

P1ease, let me know whetiler a limited form of collaboration along those lines is acceptable to you. If on the other hand a formal participation requires a substantial financial contribution - which I an unable to provide I would still be prepared to answer questions you may have concerning matters such as.the design of a suitable flame sampling system.

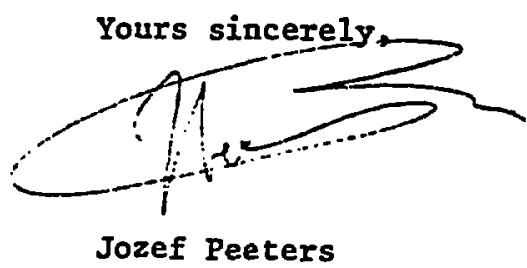


VI. MEMBERS OF PARTICIPATING RESEARCH TEAM

Prof. T. Baer, University of North Carolina (Chapel Hill) Spectroscopy; ion-molecule reactions

Dr. J. Berkowitz, Argonne National Laboratory Spectroscopy; ion molecule reactions

Prof. W. A. Chupka, Yale Universtty Spectroscopy; Ion molecule react $1: \cdots s$

Prof. J. M. Farrar, University of Rochester Molecular Beams; reactive scattering

Dr. J. R. Grover, Chemistry, BNL (Principal Spokesman) Molecular beams; reactive scattering; radiochemistry

Dr. K. W. Jones, Physics, BNL Atomic phystcs

Dr. R. B. Klemm, DEE, BNL Chemical kinetics; flame probes; combustion

Dr. M. O. Krause, Oak Ridge National Laboratory Photoelectron spectroscopy

Dr. J. B. A. Mitchell, Chemistry, BNL UHV design; ion collisions; interstellar chemistry

Prof. C-Y. Ng, Universtty of Iowa Molecular beams; photolonization

Dr. D. J. Seery, United Technology Research Center Combustion; chemical kinetics

Dr. T. Tanzawa, DEE, BNL Chemical kinetics

The above represent eight independent research groups. 